\title{
Personal Care Wastewater Treatment With Electro-coagulation and Electro-oxidation
}

\author{
Rachmad Ardhianto ${ }^{1, *}$ and Arseto Yekti Bagastyo ${ }^{1}$ \\ ${ }^{1}$ Master Program of Environmental Engineering, Sepuluh Nopember Institute of Technology, Surabaya - Indonesia
}

\begin{abstract}
Personal care wastewater contains pharmaceuticals and personal care products (PPCPs). The compounds were in organic pollutants which have to be treated before water can be discharged. Electrochemical processes such as electro-coagulation and electro-oxidation were used to remove nonbiodegradable in wastewater. Electro-coagulation as pretreatment using aluminum electrodes as anode and cathode. Electro-oxidation using Ti/Pt, and Ti/IrO2 as anode electrodes and variation of current 0,6 $\mathrm{A}, 0,7 \mathrm{~A}, 0,8 \mathrm{~A}$ and $1,0 \mathrm{~A}$. Aluminum electrodes has effectiveness in removing COD, and TSS in electrocoagulation. Using aluminum electrodes remove COD, and TSS 76.1\% (5.41 g) and 90.3\% (6.10 g). Under initial $\mathrm{pH}$, aluminum electrode does not cause a change in $\mathrm{pH}$ from initial $\mathrm{pH}$ (4.8-4.9). The removal efficiency of electrooxidation process using aluminum electrocoagulation effluent COD using $\mathrm{Ti} / \mathrm{Pt}$ and $\mathrm{Ti} / \mathrm{IrO} 2$ were $34,30 \%(1,55 \mathrm{~g})$ and $39,71 \%(1,80 \mathrm{~g})$. Increasing current when using Ti/IrO2 causes the COD removal rate to be more effective than using Ti/Pt. removal COD with $1.0 \mathrm{~A}$ gave the optimum COD removal were 34,30\% (2,3 Ah/L; 1,55 g) with Ti/Pt, and 39,71\% (2,3 Ah/L; 1,80 g) with $\mathrm{Ti} / \mathrm{IrO} 2$ compared to $0,6 \mathrm{~A}(1,4 \mathrm{Ah} / \mathrm{L}), 0,7 \mathrm{~A}(1,6 \mathrm{Ah} / \mathrm{L})$, and $0.8 \mathrm{~A}(1,9 \mathrm{Ah} / \mathrm{L})$.
\end{abstract}

Keywords: Electro-Coagulation; Electro-Oxidation; Electrode; Personal Care Wastewater.

\section{Introduction}

The characteristics of Personal Care wastewater are in the categories of pharmaceuticals and Personal Care products (PPCPs) which include drugs, cosmetic ingredients, food supplements, and other similar products [1]. These materials will have an impact as poison for humans and the environment [2] and can accumulate in ecosystem components[3]. Personal Care wastewater produces organic compounds such as hydrocarbons, proteins, esters, alcohols, and carboxylic acids. Meanwhile inorganic content includes hydroxides, salts, and heavy metal compounds. Personal Care wastewater is estimated to have very high COD> $100,000 \mathrm{mg} / \mathrm{L}$, BOD5 and TOC in high concentrations and the presence of organic nitrogen and organic phosphorus [4].

The biological treatment process is a very economical wastewater treatment process and is used to treat wastewater with biodegradable organic characteristics. Biological process is hard to be implemented this kind of waste. The low ability of biological processes on Personal Care waste is due to the high variability of the composition of the concentration and differences in the compounds of each product used [5]. Personal Care wastewater according to [6]can be processed using an advanced oxidation system, the results are a decrease of $80 \%$ COD. Electrochemical wastewater treatment can be used to treat Personal Care wastewater content with characteristics of biodegradable and non-biodegradable organics.

Electrochemical processing in environmental includes Electro-coagulation and electro-oxidation. Electro-coagulation processing is very good in processing suspended solids but is not effective in reducing organic content [7]. To overcome this problem, combined processing can be applied to obtain the efficiency of high pollutants. Electro-coagulation and electro-oxidation processes are electrochemical wastewater treatment systems[8]. Electro-coagulation and electro-oxidation processing results in better reductions than other treatments, this applies to textile wastewater[9]. An important factor in the Electrocoagulation and electrooxidation process is the use of electrodes. Aluminum electrodes during the reaction process produce three reaction zones, the first zone produces $\mathrm{Al}^{3+}$ ions at $\mathrm{pH} 1-3.5$, other zones produce hydro complexes such as $\mathrm{Al}(\mathrm{OH})_{3}$, and $\mathrm{Al}(\mathrm{OH})^{4-}$ at $\mathrm{pH}$ 4-10 [10]. The Aluminum electrode increase of $31.67 \%$ COD content and decreases energy $48.03 \%$ when compared to $\mathrm{Fe}$ electrodes [11]. In electro-oxidation, electrodes function as active surfaces in the oxidation process of organic matter [12].

It is well known that anode material plays a key role in advanced electrochemical oxidation systems, its performance depends upon the nature of coating materials on the electrodes [13]. Dimensionally Stable Anodes (DSAs) electrodes have characteristics and

* Corresponding author: rachmad.ardhianto@gmail.com 
capabilities in processing industrial waste and wastewater in general [14]. At the same current density, the energy consumption of Dimensionally Stable Anodes (DSAs) electrodes is more effective than Boron Doped Diamond (BDD) electrodes. COD removal increased significantly with increasing current density on the electrode [15]. Characteristic of COD and TSS and in personal care has a high value. Electrocoagulation used as pretreatment before, because in personal care wastewater containts high TSS. Electrocoagulation is very effective in removing TSS content so that measurement of TSS content is very necessary. TSS content is very disturbing in the electrooxidation process so that by reducing TSS at the beginning it will facilitate the electrooxidation process. COD measurements were carried out because to compare the value of the BOD/COD ratio before and Already an electrochemical process. For personal care wastewater COD, TSS and Turbidity and $\mathrm{pH}$ never been done before for measurement in electrocoagulation and electrooxidation process.

The objective of this study was to analyze the effect of aluminum electrodes on electro-coagulation process. The next objective is to analyze the influence of electrode and current in the electro-oxidation process using DSA Ti/Pt and DSA Ti/ $\mathrm{IrO}_{2}$ electrodes.

\section{Experiment}

\subsection{Wastewater Samples}

The wastewater used is personal care $\mathrm{X}$ wastewater in Semarang City. Wastewater collected from facial care (cleansing and peeling), skincare (body treatment), and hair care (hair treatment) at beauty clinics. Characteristics of Personal care wastewater show in Table 1, ratio BOD/COD in personal care is 0,2 .

Table 1. Characteristic of personal care wastewater

\begin{tabular}{|c|c|c|}
\hline No & Parameter & Concentration $\mathbf{( m g} / \mathbf{L}$ \\
\hline 1 & COD & $4.662,46$ \\
\hline 2 & TSS & $6.172,00$ \\
\hline 3 & BOD & 920,00 \\
\hline 4 & pH & 4,77 \\
\hline 5 & Turbidity & $1.047,00$ \\
\hline 6 & TDS & 517,00 \\
\hline 7 & N Total & 0,99 \\
\hline 8 & Oil \& Fat & 13,16 \\
\hline 9 & Total Coliform & - \\
\hline 10 & Cl $^{-}$ & 0,001 \\
\hline
\end{tabular}

\subsection{Electro-coagulation-Sedimentation}

The electrochemical cell used in electro-coagulation step was an acrylic container with dimensions of $12 \times 6 \times 20$ $\mathrm{cm}$, as shown in Figure 1. Alumunium electrodes, with dimensions of $13 \mathrm{~cm} \mathrm{x} 9 \mathrm{~cm} \times 1 \mathrm{~mm}$ were used in reactor as an anode electrode and a cathode electrode. Spacing between electrodes was $3 \mathrm{~cm}$. All the runs were performed with 1 liters reator of personal care wastewater with flow rate $20 \mathrm{ml} /$ minutes in the electrochemical cell. Constant voltage was controlled by DC Powers supply use MDB 305 PS with 20 volt constant voltage. Samples of the liquid were taken periodically and analyzed for COD, TSS, and $\mathrm{pH}$. For made 3 liters supernatant for electro-oxidation, electrocoagulation running for 5 hours and continue to sedimentation processes. Electro-coagulation processes will be taken periodically for $\mathrm{COD}_{\text {initi }}, \mathrm{COD}_{\mathrm{t}}, \mathrm{TSS}_{\text {init }}$, $\mathrm{TSS}_{\mathrm{t}}$, and $\mathrm{pH}$ initial and $\mathrm{pH}$ in time for 80 minutes of contact time. The sedimentation tank step was an acrylic container with dimensions of $10 \times 5 \times 20 \mathrm{~cm}$, as shown in Figure 1 Samples of the liquid were taken periodically and analyzed for TSS.

\subsection{Electro-oxidation}

The electrochemical cell used in electro-oxidation step was an acrylic container with dimensions of $20 \mathrm{x} 4 \mathrm{x}$ $12,5 \mathrm{~cm}$, as shown in Figure 2. DSA Ti/Pt electrodes and $\mathrm{Ti} / \mathrm{IrO}_{2}$ with dimensions of $1 \mathrm{~cm} \times 5 \mathrm{~cm}$ were used in reactor as an anode electrode. Carbon active electrode dimensions of $10 \mathrm{~cm} \times 5 \mathrm{~cm}$ were used in reactor as a cathode electrode. All the runs were performed with 3 liters of personal care wastewater in the electrochemical cell with flow rate $12,5 \mathrm{ml} /$ minute with batch recirculation system. Constant current was controlled by DC Powers supply with 0,6 A, 0,7 A, 0,8 A and 1,0 A constant current. Power supply using MDB PS-305DM. Samples of the liquid were taken periodically and analyzed for $\mathrm{COD}$ and $\mathrm{pH}$. $\mathrm{Na}_{2} \mathrm{SO}_{4} \quad 0,1 \mathrm{M}$ used as electrolyte in electro-oxidation to increase current initial of personal care wastewater.

\subsection{Method of Analysis}

The effect of the electro-coagulation treatment was determined by analysis of the chemical oxygen demand (COD), TSS, turbidity, and $\mathrm{pH}$ at different time intervals were determined to use using standard methods for the examination of water and wastewater [16]. COD value determined through oxidation by the mixture of chromicsulfuric acid in closed reflux and spectrophotometric reading while turbidity. TSS was determined using vacuum equipment and dry in the oven for at least 1 hour at $103^{\circ} \mathrm{C}$ to $105^{\circ} \mathrm{C}$, after that, using a desiccator to balance the temperature and weigh it. Measuring $\mathrm{pH}$ using a digital $\mathrm{pH}$ measurement tool. However, once the optimal conditions were found, the raw and treated wastewater samples were also analyzed for biochemical oxygen demand (BOD5) as indicated in standard methods for examination of water and wastewater. electrocoagulation will be interspersed with $\mathrm{EC}$ and electrooxidation will be abbreviated with EO. 


\subsection{Method of Calculation}

Determination of the optimum COD removal in the electro-coagulation and electro-oxidation process by looking at the efficiency of COD in electrochemical process using alumunium electrodes in electrocoagulation, and $\mathrm{Ti} / \mathrm{Pt}, \mathrm{Ti} / \mathrm{IrO}_{2}$ in electro-oxidation. The equation for the efficiency to be written as.

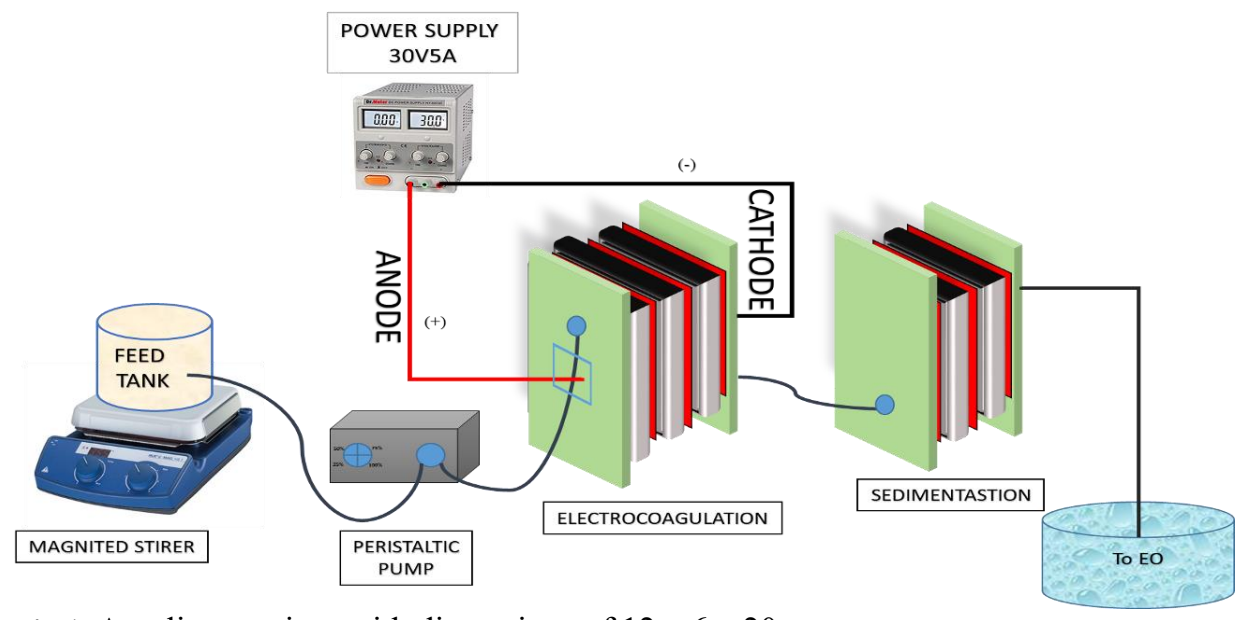

Fig.1. Acrylic container with dimensions of $12 \times 6 \times 20 \mathrm{~cm}$

$$
\text { Efficiency }=\left(\text { COD }_{t}-\text { COD }_{\text {init }}\right) /\left(C_{\text {CODit }}\right) \times 100 \%(1)
$$

Where $\mathrm{COD}_{\mathrm{t}}$ was COD taken periodically ( $\mathrm{t}$ ), $\mathrm{COD}_{\text {init }}$ was COD in fed tank or COD inlet to reactor Electro-coagulation and electro-oxidation. For electrocoagulation will be analyzed for kinetic reaction of COD, and TSS removal using first-order kinetic. For analyzing the kinetic needed concentration COD in and COD out from electro-coagulation. Efficiency of removal COD, TSS, and turbidity will be analyzed to determining the effective of aluminum electrodes in electrolysis using electro-coagulation.

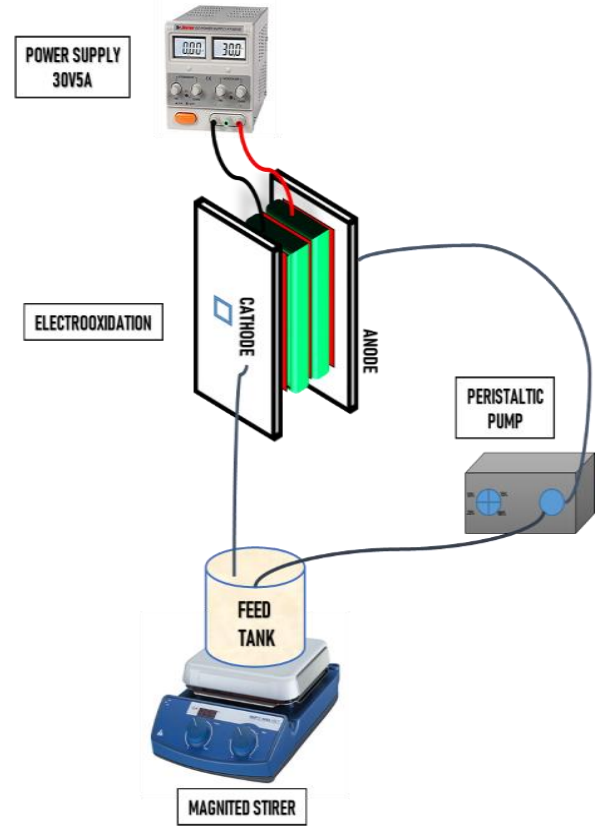

Fig.2. Electro-oxidation reactor design

\section{Result and Discussion}

\subsection{Preliminary Test of Electro-cogaulation}

Constant voltage that used in this electro-coagulation is $20 \mathrm{~V}$ related to research [17], Preliminary study of electro-coagulation with aluminum electrodes was carried out continuously with wastewater discharge of 20 $\mathrm{ml} /$ minute. Chemical Oxygen Demand (COD) characteristics of personal care wastewater are $>4500$ $\mathrm{mg} / \mathrm{L}$. The electro-coagulation system uses aluminum electrodes to has removal COD $76 \%$. Maximum efficiency, in the 60th minutes the electrolysis process produces an efficiency of $80.88 \%$ COD (Fig.3). Personal care wastewater contains Total Suspended Solids (TSS) $>6000 \mathrm{mg} / \mathrm{L}$. Electro-coagulation with aluminum electrodes produced an efficiency of $57.67 \%$ TSS in 20 minutes, whereas in the 80 minutes this system produced an efficiency of $94.86 \%$ (Fig.3). Turbidity decreased by $39 \%$ in 20 minutes, then increased by $84 \%$ at $60-120$ minutes (Figure 3).

The $\mathrm{pH}$ of treated wastewater (Figure 4) does not change significantly when compared with the $\mathrm{pH}$ of the initial wastewater. For 120 minutes the electrolysis process using Aluminum electrodes, the resulting $\mathrm{pH}$ changed at 10 minutes to 4.9 . However, the $\mathrm{pH}$ decreases when entering minutes 20 to 120 minutes. 


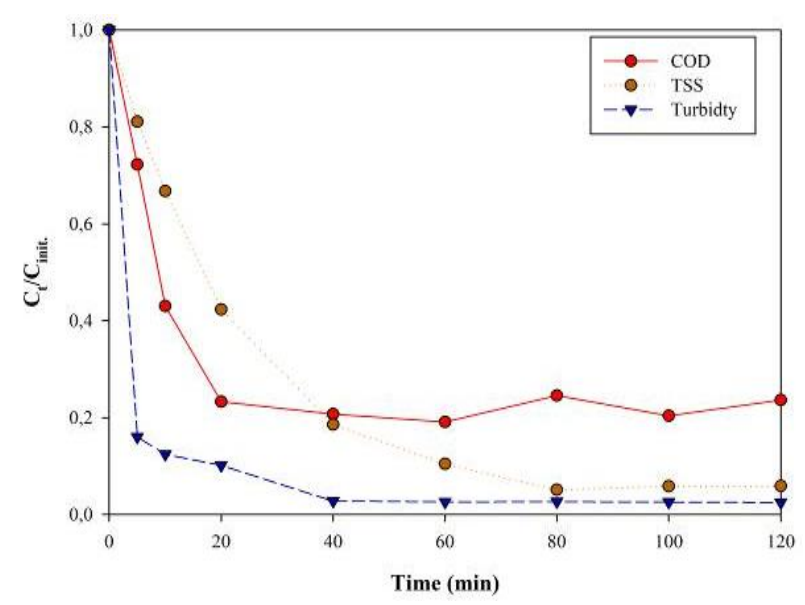

Fig. 3. Removal of organic content and turbidity with Electrocoagulation of aluminum electrodes

Figure 3. Show that $\mathrm{C}_{t} / \mathrm{C}_{\text {init }}$, influence of contact time for COD, TSS, and Turbidity removal. when contact time increases, the organic content will decrease due to the contact time between wastewater and aluminum ions in reactor. Analysis result of $\mathrm{C}_{t} / \mathrm{C}_{\text {init }} \mathrm{COD}$ value in the effect of operation time and constant voltage, as the duration of the electrolysis increases, the highest removal COD is obtained. While electrolysis increases from 5 to 40 minutes, the COD removal and TSS removal by using aluminum electrode increase to $79 \%$ and $81 \%$. In 60 to 120 minutes $\mathrm{C}_{t} / \mathrm{C}_{\text {init }}$ TSS removal increase $81 \%$ to $93,4 \%$. Turbidity removal increase from 5 minutes to 60 minutes, the removal was $85 \%$. Steady state condition from preliminary Electro-coagulation was in 40 to 120 minutes.

In the main Electro-coagulation COD and TSS, peridicaly has taken in 0 to 80 minutes. $\mathrm{pH}$ using aluminum electrode stable in 4,6-4,8 Figure 4. $\mathrm{pH}$ effective in electro-coagulation using aluminum electrode was in 4-9. Effluent from electro-coagulation will settle in sedimentation. From sedimentation produce 3 liters supernatant for 5 hours process and gives flow rate for oxidation was $12,5 \mathrm{ml} / \mathrm{min}$.

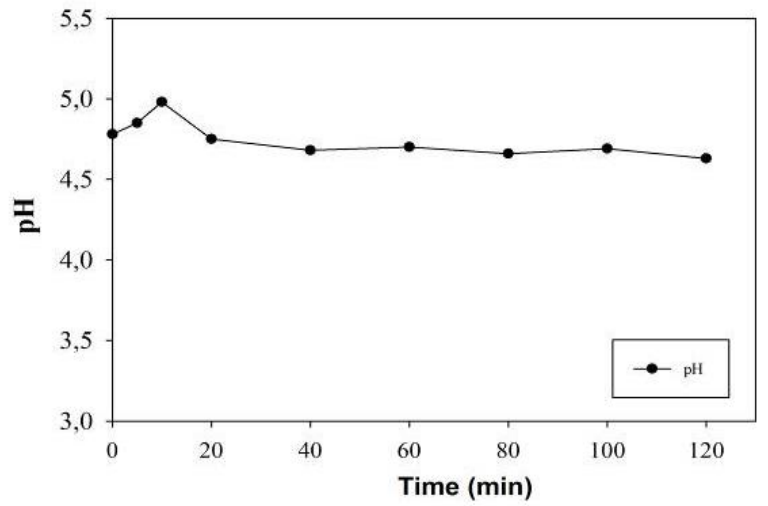

Fig. 4. $\mathrm{pH}$ value with electro-coagulation of aluminum electrodes

\subsection{Electrocogulation}

Electro-coagulation of personal care wastewater, efficiency removal COD was $70 \%$ for 40 minutes. The average COD allowance at the $0,5,10,20,40,60$, and
80 minute aluminum electrodes as follows $4438,8 \pm$ $526,23 \mathrm{mg} / \mathrm{L}, 3139,1 \pm 309,50 \mathrm{mg} / \mathrm{L}, 2051,0 \pm 264,11$ $\mathrm{mg} / \mathrm{L}, 1543,1 \pm 134,19 \mathrm{mg} / \mathrm{L}, 1083,9 \pm 99,03 \mathrm{mg} / \mathrm{L}$, $1088,8 \pm 52.22 \mathrm{mg} / \mathrm{L}$, and $1058,7 \pm 44,30 \mathrm{mg} / \mathrm{L}$. The efficiency that occurred during the Electro-coagulation treatment using aluminum electrodes is equal to $53.8 \%$ in the 10 minute, $65.2 \%$ in the 20 minute, and $75 \%$ in the 40 and 60 minutes, while at the 80 minute there is a $76 \%$ removal COD.

Using aluminum electrodes, aluminum hydroxide formed during the electrolysis process results in the production of sludge in the reactor. $\mathrm{Al}^{3+}$ ions will interact in the hydrolysis reaction $\left(\mathrm{H}_{2} \mathrm{O}\right)$ and the reaction of aluminum hydroxide produces excess sludge production resulting in color efficiency, and COD is very significant [18] (Figure5). The trend of COD or TSS removal using personal care wastewater in Electrocoagulation shows in (Figure 7). It may, therefore, be appropriate to assume that the residual COD could be related by a simple power kinetic model. The first-order kinetics in terms of residual of COD or TSS can be written as.

$(-\mathbf{d y} / \mathbf{d t})=\mathbf{k a}$

Where $(\mathrm{y})=$ residual COD or TSS $(\mathrm{mg} / \mathrm{L})$ and $(\mathrm{k})$ is the rate constant. The integration of e.q (16) gives.

$\left(\mathbf{y}(t) / \mathbf{y}_{0}\right)=\exp (-\mathbf{k t})$

where, $\left(\mathrm{y}_{0)}\right.$ and $\left(\mathrm{y}_{\mathrm{t}}\right)$ are the initial COD and COD at any time $(\mathrm{t})$. Thus, $\mathrm{y}$ plot of $\ln (\mathrm{a}(\mathrm{t})=\mathrm{y} 0)$ against $\mathrm{t}$ should give a straight line for a particular current density.

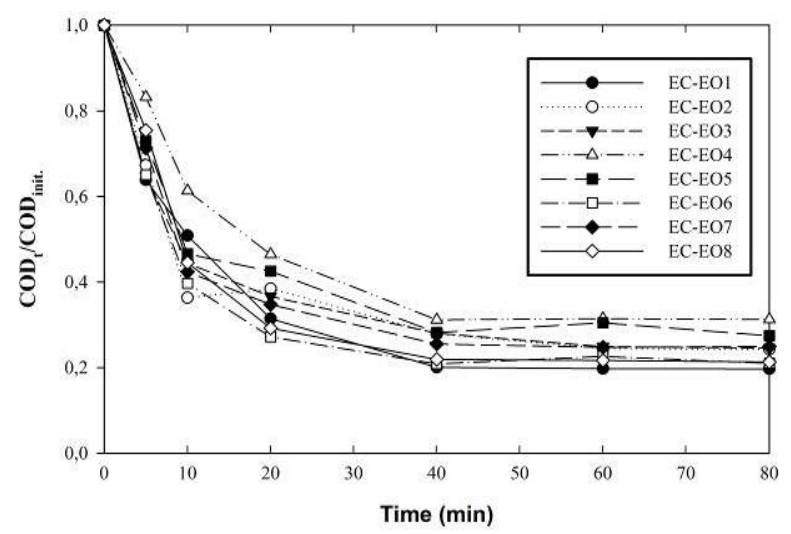

Fig. 5. COD Removal using electro-coagulation of aluminum electrodes

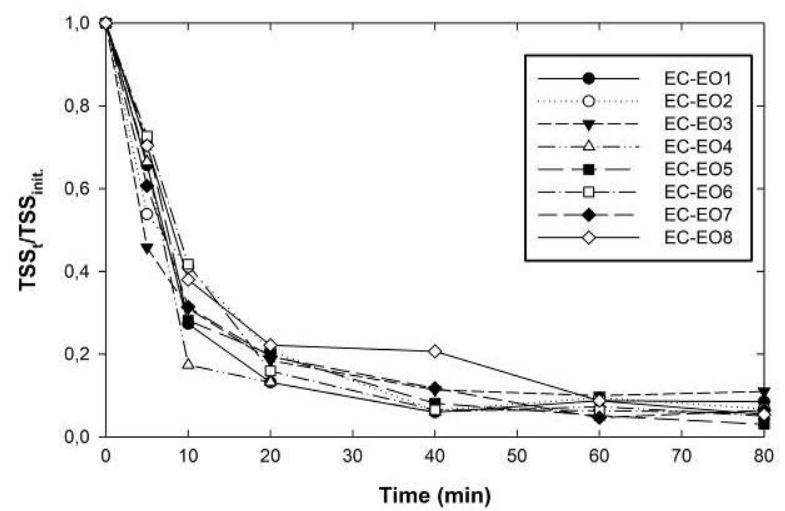

Fig. 6. Removal Rate of TSS personal care wastewater using electro-coagulation of aluminum electrodes 


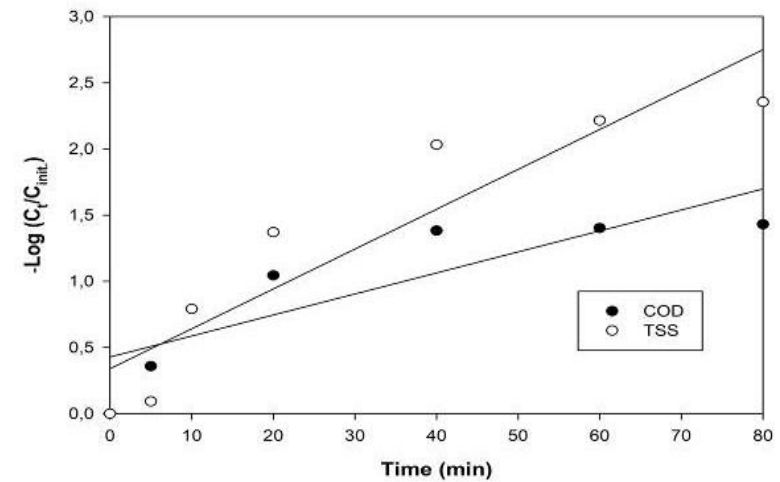

Fig. 7. Kinetic rate of TSS and COD personal care wastewater using Electro-coagulation of aluminum electrodes

Figure 7 shows such a plot as a rate of COD and TSS removal. The kinetic constants for COD removal is 0,0398 min- $^{1}$ and the $\mathrm{R}$ square of the kinetic rate is 0,7316 (Figure7). Contrast in TSS removal, removal TSS during electro-coagulation is 93\% TSS show in (Figure 6) for 80 minute electrolysis shown in (Figure 7). For the kinetic constants of removal rate of TSS is 0,0405 for the 80 minutes electro-coagulation. Based on the Figure 7 provides information that the electro-coagulation process is very dependent on the time of electrolysis, in addition to the voltage and current strength. The longer the electrolysis time process will result in high TSS removal efficiency. In 40 until 80 minutes give the best result of TSS removal. $\mathrm{pH}$ is a vital parameter in electrocoagulation, the electrolysis process is very dependent on the type of wastewater and the original $\mathrm{pH}$ of wastewater [19]. Personal care wastewater has the $\mathrm{pH}$ characteristics of acidic $\mathrm{pH}$ with a $\mathrm{pH}$ range of 4.7-5.0 (Figure 8). To determine the effect of $\mathrm{pH}$ value, [20] explained that at $\mathrm{pH}$ above 6 in the Electro-coagulation process, more than $84 \%$ COD was removal, $90 \%$ TSS was removal and $91 \%$ of the color was changed. In the application of the electro-coagulation process with aluminum electrodes, there was an increase in $\mathrm{pH}$ value in the electro-coagulation process. However, the increase was not significant. Process of electrocoagulation show in Figure 9.

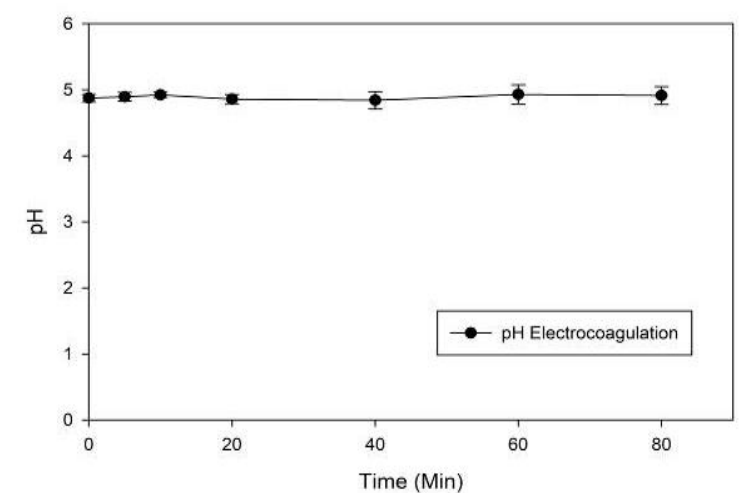

Fig. 8. $\mathrm{pH}$ value during electro-coagulation using aluminum electrodes.
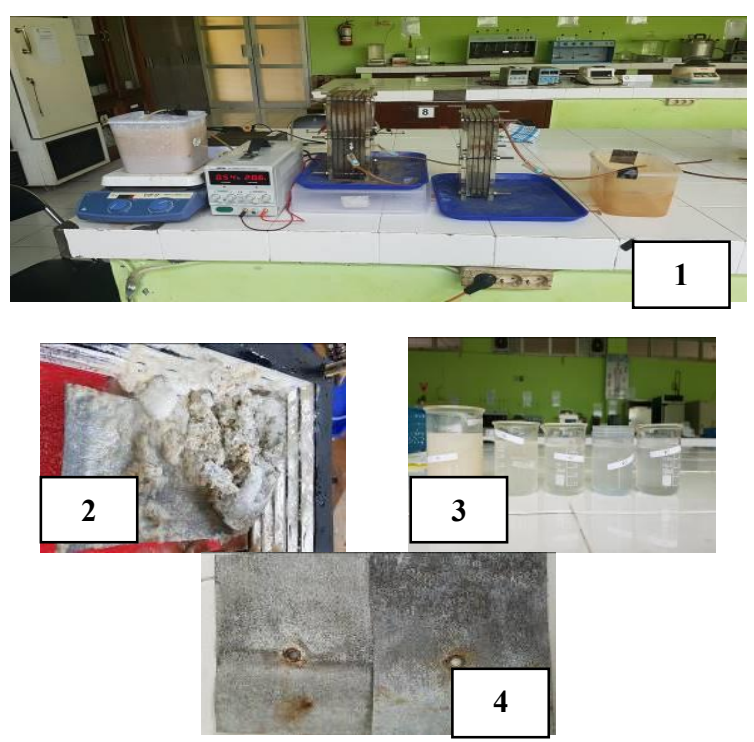

Fig. 9. Reactor electrocoagulation-sedimentation (1) process electrocoagulation and sedimentation, (2) sludge of electrocoagulation, (3) supernatant, (4) electrode after process.

During electro-coagulation operation various reaction takes place in the electrochemical cell. The first initiation of electro-coagulation was the oxidation of sacrificial aluminum anode yielding $\mathrm{Al}^{3+}$ ions. At the cathode, the gydroxyl ion is produced by water hydrolysis. The $\mathrm{Al}^{3+}$ ions combined with $\mathrm{OH}^{-}$ions to form aluminum metal ion hydroxides create a network of gelatinous structure which entraps the dissolved destabilized mass and particilates and initiates formation of flocs. With passage of time, the floc size will increase and the smaller flocs float due to buoyancy created by hydrogen bubbles generated at the cathode and the participate settles down [21].

At anode, $\mathrm{Al}^{3+}$ ions are generated by the following reaction (3)

$\mathrm{Al}(\mathrm{s}) \longrightarrow \mathrm{Al}^{3+}(\mathrm{aq})+3 \mathrm{e}^{-}$

At the cathode, Hydrogen is generated due to hydrolysis of water. Hydrolysis production is $\mathrm{pH}$-dependent.

$2 \mathrm{H}_{2} \mathrm{O}(\mathrm{l})+2 \mathrm{e}^{-} \longrightarrow \mathrm{H}_{2}(\mathrm{~g})+2(\mathrm{OH})^{-}(\mathrm{aq})$

Oxygen evolution can compete with aluminum dissolution at the anode via the following reaction:

$2 \mathrm{H}_{2} \mathrm{O}(\mathrm{l}) \longrightarrow \mathrm{O}_{2}(\mathrm{~g})+4 \mathrm{H}^{+}(\mathrm{aq})+4 \mathrm{e}^{-}$

The $\mathrm{Al}^{3+}$ and $\mathrm{OH}^{-}$ions produced at the anode and cathode, respectively, react to form various aluminum hydrolyzed products. The concentration of the hydrolyzed aluminum species depends on the aluminum concentration and the solution $\mathrm{pH}$. The $\mathrm{Al}^{3+}$ products can be calculated from the following stability constants:

$\mathrm{Al}^{3+}+\mathrm{H}_{2} \mathrm{O} \longrightarrow \mathrm{Al}(\mathrm{OH})_{2}{ }^{+}+\mathrm{H}^{+} \mathrm{pK} 1=4,95$
$\mathrm{Al}(\mathrm{OH})^{2+}+\mathrm{H}_{2} \mathrm{O} \longrightarrow \mathrm{Al}(\mathrm{OH})_{2}{ }^{+}+\mathrm{H}^{+} \mathrm{pK} 2=5,6$
$\mathrm{Al}(\mathrm{OH})^{2+}+\mathrm{H}_{2} \mathrm{O} \longrightarrow \mathrm{Al}(\mathrm{OH})_{3}+\mathrm{H}^{+} \mathrm{pK} 3=6,7$
$\mathrm{Al}(\mathrm{OH})^{3+}+\mathrm{H}_{2} \mathrm{O} \longrightarrow \mathrm{Al}(\mathrm{OH})_{4}{ }^{-}+\mathrm{H}^{+} \mathrm{pK} 4=5,6$

Aluminum species behave like coagulants and the destabilization of colloidal particles is achieved through the adsorption of these $\mathrm{Al}$ species on colloidal particles neutralizing the colloidal particle charge [22]. Hydrogen bubbles formed at the cathode can adsorb on coagulated suspended particulates and droplets forming flocs 
inducing their flotation [23]. Initial $\mathrm{pH}$ gives the first formation for insitu coagulation using aluminum electrodes. Based analysis characteristic of EDX (Figure 10) and SEM (Figure 11) of sludge in electrocoagulation using aluminum electrodes give result that during electrocoagulation in personal care has formation $\mathrm{Al}_{2} \mathrm{O}_{3}$ (Figure 11) in the sludge, Concentration of $\mathrm{Al}_{2} \mathrm{O}_{3}$ is $19,89 \%$.

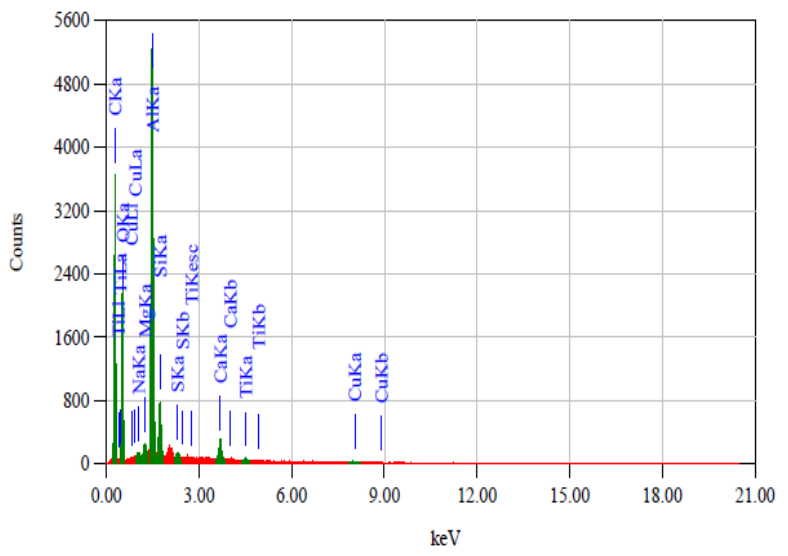

Fig. 10. Result of EDX oxide of sludge electrocoagulation.

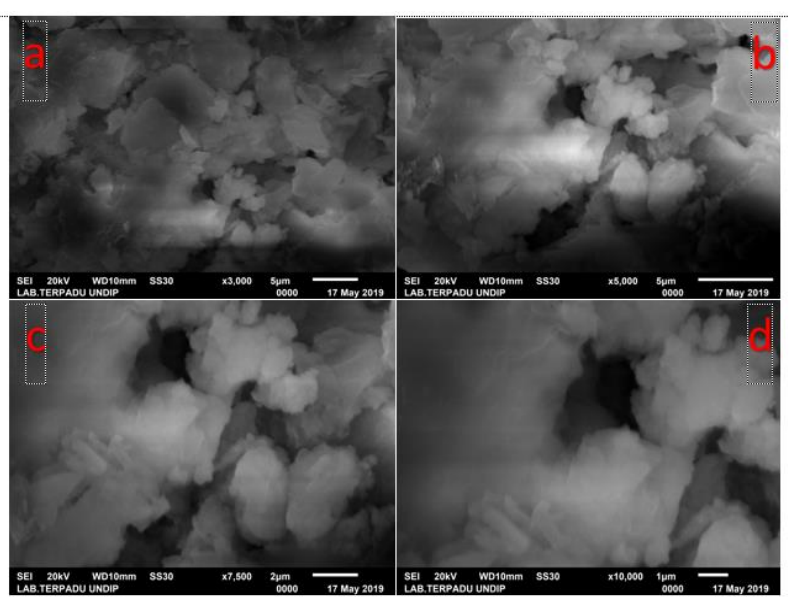

Fig. 11. SEM of sludge electrocoagulation using alumunium electrode (a 3000x, b 5000x, c 7500x, d 10.000x).

\subsection{Sedimentation}

After electro-coagulation process, sedimentation process was needed for removal of TSS in the personal care wastewater. The result of sedimentation is.

Table 2. The Result of Sedimentation

\begin{tabular}{|c|c|c|c|c|}
\hline EC & COD (mg/L) & TSS (mg/L) & Turbidity & pH \\
\hline EC 1 & 1081,25 & 696 & 103,0 & 4,75 \\
\hline EC 2 & 1068,75 & 696 & 103,0 & 4,83 \\
\hline EC 3 & 1018,75 & 696 & 85,6 & 4,90 \\
\hline EC 4 & 1003,12 & 536 & 105,6 & 4,87 \\
\hline EC 5 & 1084,37 & 816 & 156,3 & 4,87 \\
\hline EC 6 & 1087,50 & 772 & 160,3 & 4,97 \\
\hline EC 7 & 1018,75 & 696 & 85,6 & 4,90 \\
\hline EC 8 & 1003,12 & 536 & 105,6 & 4,87 \\
\hline
\end{tabular}

Note: EC 1 is electrocoagulation with aluminum electrodes

Sedimentation for the effluent Electro-coagulation has a function for determining the flow rate supernatant from sedimentation to electrooxidation process. The result of sedimentation is 3 liter supernatants for the electro-oxidation with 5 hour proses electro-coagulation and sedimentation. The rate of TSS removal only has $20 \%-30 \%$ removal of TSS in sedimentation.

\subsection{Electro-oxidation DSA Ti/Pt and Ti//rO2}

The use of Dimensionally Stable Anodes (DSA) electrodes in wastewater treatment processes is a technology that can reduce operational costs and investment costs [24]. Supernatant result from electrocoagulation and sedimentation continues to electrooxidation. Electrode material has an important role in electrochemical processes. The usual electrodes used are anode electrodes Electro-oxidation for the effluent Electro-coagulation using aluminum electrode are using DSA Ti/Pt and DSA Ti//rO ${ }_{2}$. The constant current used in the system are $0,6,0,7,0,8$, and $1,0 \mathrm{~A}$. These electrodes provide high electrocatalyst activity, stability to corrosion on the anode and have excellent mechanical properties. By using these electrodes the oxidation process can occur through direct oxidation such as electron exchange between contaminants and electrode surfaces or with indirect processes with active species which have high oxidizing power such as peroxide, $\mathrm{O}_{3}$, and active chlorine.

$\mathrm{Ti} / \mathrm{Pt}$ electrodes produce a removal COD (Figure 12) show that $0,43 \mathrm{~g}(1,4 \mathrm{Ah} / \mathrm{L}), 0,83 \mathrm{~g}(1,6 \mathrm{Ah} / \mathrm{L}), 0,92$ $\mathrm{g}(1,9 \mathrm{Ah} / \mathrm{L})$ and $1,55 \mathrm{~g}(2,3 \mathrm{Ah} / \mathrm{L})$ or $34 \%$ in 7 hours treatment. Low efficiency in removal of COD in $\mathrm{Ti} / \mathrm{Pt}$ from electro-coagulation-aluminum electrodes can be caused due to the oxidation process of anode material in acidic media which is very reactive to the reaction process of organic matter by the process of releasing hydroxyl radicals to oxygen [25]. $\mathrm{pH}$ effects for performance of $\mathrm{Ti} / \mathrm{Pt}$ electrodes. initial $\mathrm{pH}$ in wastewater is 4.7-4.9 (Figure 13). Based on [26] the $\mathrm{pH}$ value of 6.0 can provide a COD removal efficiency value that increases up to $82 \%$ in 120 minutes of wastewater by electro-oxidation process.

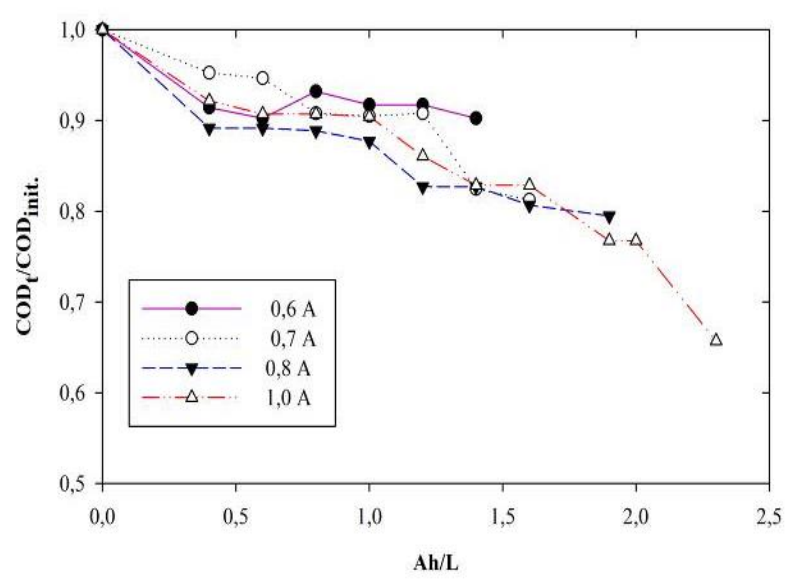

Fig. 12. $\mathrm{OD}_{t} / \mathrm{COD}_{\text {init }}$ in electro-oxidation using $\mathrm{Ti} / \mathrm{Pt}$ 


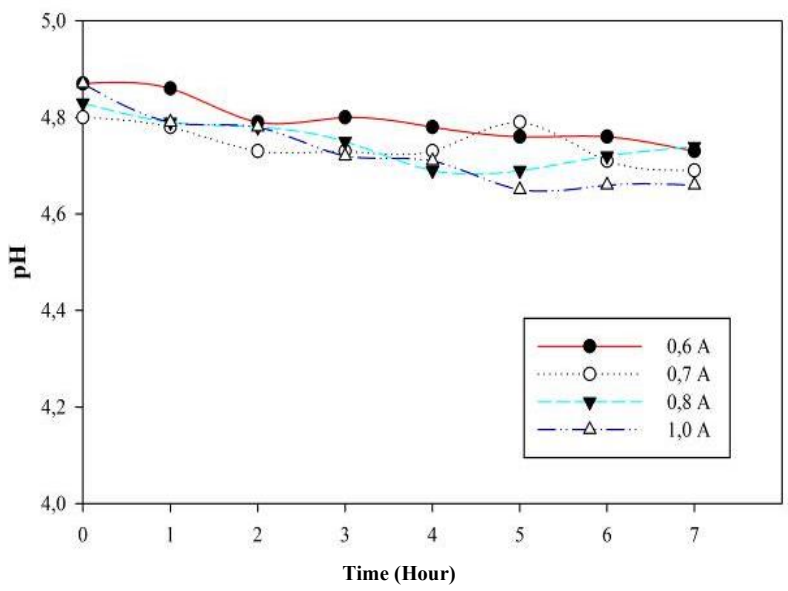

Fig. 13. $\mathrm{pH}$ in electro-oxidation using $\mathrm{Ti} / \mathrm{Pt}$

DSA Ti/ Pt electrode is a type of electrode that has a low potential oxidation function. However, the function of these electrodes will be more effective if in the oxidation process wastewater treatment includes active oxidant species such as active chlorine, persulfate, and Ozone [27]. The increasing current (Figure 11) will cause the acceleration of the reaction and increase the production of active chlorine sepsies capable of oxidizing organic matter faster with the occurrence of organic reduction competition with $\mathrm{M}\left({ }^{*} \mathrm{OH}\right)$ formed from the oxidation process. Thus, in the case of electrooxidation using personal care waste, there is a slow oxidation process of organic content because this type of waste is aromatic waste and does not contain the initials of active chlorine species so that the oxidation process will only be carried out by relying on the formation of $\mathrm{M}$ $(* \mathrm{OH})$.

The result using DSA $\mathrm{Ti} / \mathrm{IrO}_{2}$ is contrasting with DSA Ti/Pt for removal COD in electrooxidation. $\mathrm{Ti} / \mathrm{IrO}_{2}$ electrodes in the process provide treatment for COD removal of $0,38 \mathrm{~g}(1,4 \mathrm{Ah} / \mathrm{L}), 0,66 \mathrm{~g}(1,6 \mathrm{Ah} / \mathrm{L}), 1,01 \mathrm{~g}$ $(1,9 \mathrm{Ah} / \mathrm{L})$, and $1.80 \mathrm{~g}(2,3 \mathrm{Ah} / \mathrm{L})$, or $39,7 \% \mathrm{COD}$ (Figure 13) in 7 hours electrolysis. The best effect for personal care wastewater achieved in current 1,0 A using $\mathrm{Ti} / \mathrm{Pt}$ electrode.

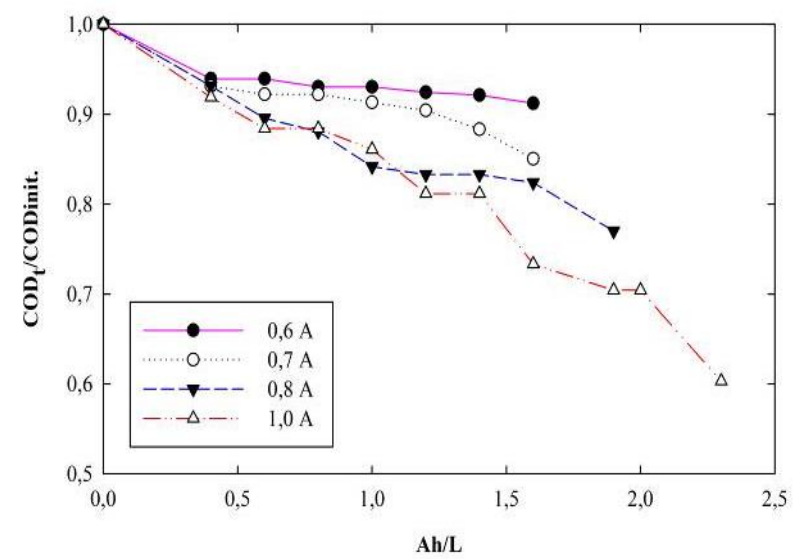

Fig. 14. $\mathrm{COD}_{t} / \mathrm{COD}_{\text {init }}$ in electro-oxidation using $\mathrm{DSA} \mathrm{Ti} / \mathrm{IrO}_{2}$

The increase in current strength has a very significant influence on the oxidation process of the organic content of personal care wastewater. Increasing current $0,6 \mathrm{~A}$ to $0,7 \mathrm{~A}$ using DSA Ti/Pt give removal of
$0,38 \mathrm{~g}(1,4 \mathrm{Ah} / \mathrm{L})$ of COD within 7 hours is successfully carried out within 4 hours in $0,7 \mathrm{~A}$. 1,01 $\mathrm{g}$ of COD was successfully remove with a current of $0,8 \mathrm{~A}$ within 7 hours $(1,9 \mathrm{Ah} / \mathrm{L})$, but with current 1,0 A 1,01 gram COD was successfully degradation within 5 hours $(1,6 \mathrm{Ah} / \mathrm{L})$.

The best effect for personal care wastewater achieved in current $1,0 \mathrm{~A}$ using $\mathrm{Ti} / \mathrm{IrO}_{2}$ electrode. Anode $\mathrm{Ti} / \mathrm{IrO}_{2}$ electrode is an electrode which is an indirect oxidation type. This electrode will provide an increase in COD removal in the presence of an electrolyte solution or the presence of free oxidant in solution. Anode $\mathrm{Ti} / \mathrm{IrO}_{2}$ electrodes were conductive oxidation electrodes that function at low voltages for high electrochemical activity processes to lead to the process of oxygen evolution, but this type of electrode has a low chemical reactivity to oxidation of organic matter in water [28]. With the direct oxidation process, using anode $\mathrm{Ti} / \mathrm{IrO}_{2}$ electrodes with personal care wastewater provides very small COD removal results, which only reaches $39,83 \%$ COD removal in 7 hours. This is based on the basic nature of the electrode which has a low chemical reactivity against oxidation of organic matter. In addition, based on [29], modified $\mathrm{Ti} / \mathrm{IrO}_{2}$ electrodes with $\mathrm{TiO}_{2}$ gave more hydroxyl radical results of 55\% compared to $\mathrm{Ti} / \mathrm{IrO}_{2}$ electrodes in the oxidation process in a certain time.

$\mathrm{Ti} / \mathrm{IrO}_{2}$ electrodes are independent of the $\mathrm{pH}$ value of wastewater during the electrolysis process. This shows that these electrodes perform well in a wide $\mathrm{pH}$ range, making $\mathrm{pH}$ effect in the electrolysis process not necessary. Many factors for electrochemical processes using $\mathrm{Ti} / \mathrm{Pt}$ and $\mathrm{Ti} / \mathrm{IrO}_{2}$ electrode. $\mathrm{pH}$, current, and characteristic of initial personal care wastewater mostly factors effect in oxidation process. personal care wastewater contains polycyclic musks and personal care wastewater do not have any chlorine in solution. Chlorin mostly effects in DSA electrodes in oxidation process.

\subsection{Ratio BOD/COD}

The results of COD removal using $\mathrm{Ti} / \mathrm{Pt}$, and $\mathrm{Ti} / \mathrm{IrO}_{2}$ electrodes have a tendency according to the results of the oxygen evolution potential $(\mathrm{BDD}>\mathrm{DSA}>\mathrm{Ti} / \mathrm{Pt})[28]$.

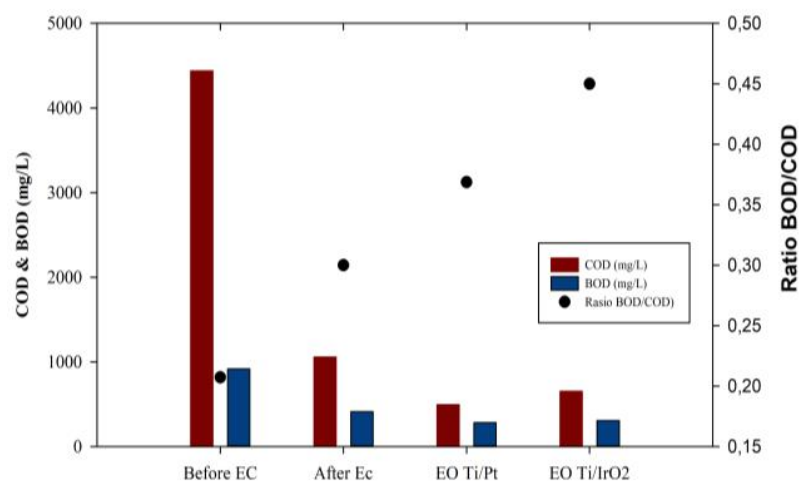

Fig.15. Ratio BOD/COD using electro-oxidation with DSA $\mathrm{Ti} / \mathrm{Pt}$ and DSA Ti/IrO 2 electrode

The tendency to use the type of effluent from EC$\mathrm{Al}$ wastewater will produce the best COD efficiency for $\mathrm{Ti} / \mathrm{IrO}_{2}$ sequentially is $\mathrm{Ti} / \mathrm{IrO}_{2}>\mathrm{Ti} / \mathrm{Pt}$. Based on the study 
of the $\mathrm{BOD} / \mathrm{COD}$ ratio generated from the electrooxidation process with $\mathrm{Ti} / \mathrm{Pt}$ and $\mathrm{Ti} / \mathrm{IrO}_{2}, \mathrm{BOD} / \mathrm{COD}$ ratio results from $\mathrm{Ti} / \mathrm{IrO}_{2}$ electrodes were better than the $\mathrm{Ti} / \mathrm{Pt}$ electrodes in practice for personal care wastewater. Both of these electrodes give a BOD/COD ratio $>0.3$. Anode $\mathrm{Ti} / \mathrm{IrO}_{2}$ produces a better $\mathrm{BOD} / \mathrm{COD}$ ratio than $\mathrm{Ti} / \mathrm{Pt}$ when using EC-Al wastewater which is an increase of $0.3-0.45$, while $\mathrm{Ti} / \mathrm{Pt}$ is $0.3-0.37$.

$\mathrm{BOD}_{5}$ was measured to evaluate the electrochemical oxidation process of personal care waste. After 7 hours of processing, Electro-oxidation with a strong current of 1.0 A gives an increase in the biodegradability index (Figure 15). An increase biodegradability index occurred with the use of DSA $\mathrm{Ti} / \mathrm{Pt}$, and DSA $\mathrm{Ti} / \mathrm{IrO}_{2}$ electrodes. [30] explained that using electrodes made from Metal Oxide can increase the $\mathrm{BOD} / \mathrm{COD}$ ratio during the electro-oxidation process. There are two types of oxidation mechanisms for organic matter in an electrochemical system. (i) an electrochemical conversion process in which the organic content will be transformed to become biodegradable organic content. (ii) the electrochemical combustion process to the organic content into $\mathrm{CO}_{2}$ and $\mathrm{H}_{2} \mathrm{O}$ [31].

BOD5 was measured to evaluate the electrochemical oxidation process of personal care waste. Electrooxidation with a strong current of $1.0 \mathrm{~A}$ gives an increase in the biodegradability index. An increase in the biodegradability index occurred with the use of DSA Ti/Pt, and DSA $\mathrm{Ti} / \mathrm{IrO}_{2}$. Furthermore [30] explained that using electrodes made from Metal Oxide can increase the ratio of BOD/COD during the electrooxidation process.

\section{Conclusion}

Aluminum electrodes have effectiveness in removing COD, and TSS from personal care wastewater. Aluminum electrodes remove COD, and TSS 76.1\% $(5.41 \mathrm{~g})$ and $90.3 \%(6.10 \mathrm{~g})$. Under initial $\mathrm{pH}$, aluminum electrode does not cause a changes $\mathrm{pH}$ from the initial $\mathrm{pH}$ (4.8-4.9). Removal efficiency of aluminum electrocoagulation effluent COD using Ti/Pt and $\mathrm{Ti} / \mathrm{IrO}_{2}$ were $34,30 \%(1,55 \mathrm{~g})$ and $39,71 \%$ (1,80 g). The increasing current when using $\mathrm{Ti} / \mathrm{IrO}_{2}$ causes the COD removal rate to be more effective than using $\mathrm{Ti} / \mathrm{Pt}$. Removal for COD with $1.0 \mathrm{~A}$ gave the optimum COD allowance of $34,30 \%(2,3 \mathrm{Ah} / \mathrm{L} ; 1,55 \mathrm{~g})$ with $\mathrm{Ti} / \mathrm{Pt}$, and $39,71 \%(2,3 \mathrm{Ah} / \mathrm{L} ; 1,80 \mathrm{~g})$ with $\mathrm{Ti} / \mathrm{IrO}_{2}$ compared to 0,6 A $(1,4 \mathrm{Ah} / \mathrm{L}), 0,7 \mathrm{~A}(1,6 \mathrm{Ah} / \mathrm{L})$, and $0.8 \mathrm{~A}(1,9 \mathrm{Ah} / \mathrm{L})$ using electrocoagulation effluent of aluminum electrodes.

\section{References}

1. Santiago Esplugas, Daniele M. Bila, Luiz Gustavo T. Krause, and M'arcia Dezotti, J. Hazard. Mater., 149, pp. 631-642, (2007).

2. C. Mie'ge, J.M. Choubert, L. Ribeiro, M. Euse be, and M. Coquery, Environ. Pollut., 157, pp. 1721-1726, (2009).
3. R. Reif, S. Suárez, F. Omil, and J.M. Lema, Desalination, 221, pp. 511-517, (2008).

4. B. Jan, J. NAUMCZYK, P. MARCINOWSKI, and M. Kucharska, 65, (2011).

5. A. Joss et al., Water Res., 39, no. 14, pp. 3139 3152,(2005).

6. F. Aloui, S. Kchaou, and S. Sayadi, J. Hazard. Mater., 164, pp. 353-359, (2009).

7. A. K. Verma, R. R. Dash, and P. Bhunia, J. Environ. Manage., 93, no. 1, pp. 154-168, (2012).

8. C. A. Martínez-Huitle and E. Brillas, Appl. Catal. B Environ., 87, no. 3, pp. 105-145, (2009).

9. E. Gilpavas, P. Arbeláez-Castaño, J. Medina, and D. Acosta, 76. (2017).

10. C. E. Barrera-Díaz, P. Balderas-Hernández, and B. Bilyeu, "Electrocoagulation: Fundamentals and Prospectives," in Electrochemical Water and Wastewater Treatment, pp. 61-76, (2018).

11. S. Camcioglu, B. Ozyurt, and H. Hapoglu, Process Saf. Environ. Prot., 111, pp. 300-319, (2017).

12. A. L. Fornazari, G. Malpass, D. Miwa, and A. Motheo, 223. (2012).

13. A. Yaqub, M. H. Isa, H. Ajab, S. R. Mohamed Kutty, and E. Henry Ezechi, 24, (2017).

14. O. Scialdone, S. Randazzo, A. Galia, and G. Filardo, Electrochimica Acta, 54, no. 4, pp. 12101217, (2009).

15. M. Zhou, L. Liu, Y. Jiao, Q. Wang, and Q. Tan, Desalination, 277, pp. 201-206, (2011).

16. L. S. Clesceri, A. E. Greenberg, and A. D. Eaton, Standar Methods for The Examination of Water and Wastewater, 20th ed. American Public Health Association, (1999).

17. D. Darmadi, M. Lubis, H. Sofyan, A. Chairunnisak, and B. Arifin, 18. (2018).

18. V. Khandegar and A. K Saroha, 128C (2013).

19. K. Bensadok, S. Benammar, F. Lapicque, and G. Nezzal, J. Hazard. Mater., 152, pp. 423-430, (2008).

20. A. Samir, S. Chelliapan, Z. Zakaria, and S. A. Abbas, 10. (2015).

21. V. Sangal, I. Mishra, and J. Kushwaha, 48. (2013).

22. J. Duan and J. Gregory, Adv. Colloid Interface Sci., 100-102, pp. 475-502, (2003).

23. P. K. Holt, G. W. Barton, M. Wark, and C. A. Mitchell, Colloids Surf. Physicochem. Eng. Asp., 211, pp. 233-248, (2002).

24. E. Chatzisymeon, A. Dimou, D. Mantzavinos, and A. Katsaounis, J. Hazard. Mater., 167, pp. 268 274, (2009).

25. A. Kapałka, G. Fóti, and C. Comninellis, 38. (2008).

26. V. de O. Campos, L. B. Do Amaral, A. M. S. Solano, D. M. De Araújo, C. A. Martínez-Huitle, and D. R. da Silva, (2018).

27. E. Lacasa, J. Llanos, P. Cañizares, and M. A. Rodrigo, Chem. Eng. J., 184, pp. 66-71, (2012).

28. G. Chen, Sep. Purif. Technol., 38, no. 1, pp. 1141, (2004).

29. D. Chun, C.-R. Lim, H.-S. Lee, W.-S. Yoon, T.-K. Lee, and D. K. Kim, J. Water Process Eng., 26, pp. 1-9, (2018). 
30. D. Shao, J. Liang, X. Cui, H. Xu, and W. Yan, Chem. Eng. J., 244, pp. 288-295,(2014).

31. C. Comninellis, Electrochimica Acta, 39, pp. 1857-1862, (1994). 